\title{
FLORA OF THE COBBLED STREETS AND PAVEMENTS IN THE MEDITERRANEAN OLD CITY OF DUBROVNIK DURING THE COVID-19 LOCKDOWN
}

\author{
Nenad Jasprica $^{1 *}$ \& Milenko Milović ${ }^{2}$ \\ ${ }^{1}$ Institute for Marine and Coastal Research, University of Dubrovnik, HR-20000 Dubrovnik, Croatia \\ ( ${ }^{*}$ corresponding author: nenad.jasprica@unidu.hr) \\ 2“Antun Vrančić” Grammar School, Put Gimnazije 64, HR-22000 Šibenik, Croatia
}

Jasprica, N. \& Milović, M.: Flora of the cobbled streets and pavements in the Mediterranean Old City of Dubrovnik during the COVID-19 lockdown. Nat. Croat., Vol. 29, No. 1, 19-28, Zagreb, 2020.

The flora of the cobbled streets and pavements in the Old City of Dubrovnik, South Croatia, was studied in unusual circumstances with lack of trampling due to the Covid-19 lockdown in April 2020. The features of the flora through analyses of taxonomic composition, life forms, chorotypes and the phytosociological character of species found at eight sites in Dubrovnik Old City and along a transect line on the main street (Stradun) are reported. Altogether, 57 plant species and three subspecies were found. Therophytes, Cosmopolitans and taxa from the Papaveretea rhoeadis and Chenopodietea prevailed. The study highlights the importance of the investigation of both flora and vegetation within Dubrovnik's city historical centre.

Key words: eastern Adriatic, floristic survey, man-made habitats, Mediterranean, taxonomy

Jasprica, N. \& Milović, M.: Flora na ulicama i pločnicima u dubrovačkoj staroj gradskoj jezgri u vrijeme karantene uzrokovane epidemijom COVID-19. Nat. Croat., Vol. 29, No. 1, 19-28, Zagreb, 2020.

U travnju 2020. istraživana je flora ulica i pločnika u staroj gradskoj jezgri u Dubrovniku tijekom razdoblja karantene uslijed epidemije COVID-19. U radu su opisane florističke značajke temljem analize taksonomskog sastava, životnih oblika, flornih elemenata i fitocenološke pripadnosti biljnih svojti na osam lokaliteta te na transektu uzduž Straduna. Ukupno je pronađeno 57 biljnih vrsta i tri podvrste. Najveći udio u flori imali su terofiti, kozmopoliti te svojte svojstvene vegetacijskim razredima Papaveretea rhoeadis i Chenopodietea. Studija ističe važnost istraživanja flore i vegetacije u povijesnoj jezgri grada Dubrovnika.

Ključne riječi: antropogena staništa, flora, istočni Jadran, Sredozemlje, taksonomija

\section{INTRODUCTION}

Dubrovnik is a city located on the eastern coast of the Adriatic Sea in South Croatia $\left(42^{\circ} 39^{\prime \prime} \mathrm{N}, 18^{\circ} 04^{\prime \prime} \mathrm{E}\right)$. The city (historically known as Ragusa) was founded in the $7^{\text {th }}$ century on a limestone hill that enclosed the bay of the Old City Port on the seaward side (HARRIS, 2006). The original core was expanded by filling the shallows that separated it from the mainland (today's Stradun or Placa). Two entrances to the Old City, Pile in the west and Ploče in the east, and the city walls (built over the centuries) define the image of the medieval town. The Old City (area of $0.15 \mathrm{~km}^{2}$ ), in the shape of an irregular pentagon surrounded by walls, with the wide central Stradun Street and alleys, stairs and squares is the focus of the wider Dubrovnik area (Fig. 1). In 1979, the city of Dubrovnik 
joined the UNESCO list of World Heritage Sites. Today, its total population is 42,600 (census 2011), with 1,557 inhabitants in the Old City center (internal census 2016).

Dubrovnik is one of the most prominent tourist destinations of the Mediterranean region. Croatia generally and Dubrovnik in particular has seen a steady annual growth in tourism over the past decade (MRĐA \& CARIĆ, 2019). In 2019, 1.44 million arrivals and 4.37 million overnights were recorded in Dubrovnik. Overcrowding by cruise tourism (the total number of cruise-ship visitors was 800,000 in 2019) threatens the degradation of both the environment and of particular historical sites (CARIĆ \& MACKELWORTH, 2014).

According to Köppen's climate classification (KöPPEN \& GEIGER, 1954; STRÄßER, 1998) the city lies within the Csa climate zone, i.e. the Quercetea ilicis vegetation zone, where the climate is typically Mediterranean: mild and rainy winters, warm and dry summers, and an extended period of sunshine throughout the year. The average annual temperature is $16^{\circ} \mathrm{C}$, while average annual rainfall is $1,294 \mathrm{~mm}$ (JAspricA et al., 2010).

In urban ecosystems, the structures of plant and animal communities are determined by both anthropogenic and natural processes (e.g. SzLAVECz et al., 2011; KowARIK \& VON DER LiPPE, 2018, and references therein). In general, previous studies have advanced the understanding of urban flora in Dubrovnik (JASPRICA et al., 2010, 2020), but full interpretation of floral diversity did not incorporate an analysis of both historical and recent city activity.

In this study we investigated the flora of the cobbled streets and pavements in the Old City of Dubrovnik in April 2020, when residents and visitors were absent from the streets due to the COVID-19 lockdown. Dubrovnik has not been so quiet and not-trampled since the 1990s war; in "normal" circumstances thousands upon thousands of feet would have been planishing the streets of the Old City. In these unusual circumstances, we were able for the first time to inventory the flora in the heart of the Old City. The object of our study was an analysis of flora based on taxonomic composition, life forms, chorotypes and the phytosociological character of plant species.

\section{MATERIAL AND METHODS}

The study was carried out over April 20-24, 2020. Eight sites were randomly chosen in different parts of the Old City of Dubrovnik, including a transect line along the main street (Stradun) (Fig. 1). The area of the sites (squares and streets) ranged from $250 \mathrm{~m}^{2}$ (near the Cathedral) to $1,900 \mathrm{~m}^{2}$ (Stradun) (Fig. 2E). In this study, the flora on the vertical wall surfaces was not studied (see JAspricA et al., 2020), since we were interested in the lack of feet, i.e. the normal wear to which the ancient pavement stones of the Old City are subjected.

Taxa were determined using the standard determination keys, books and guides reported in JAsprica \& Milović (2016) and Milović et al. (2016). The taxa in the list are given in alphabetical order of genera and species. Biological form was reported according to categories given in Pignatti (1982), these being based in turn on the classification of RAUNKIAER (1934). Regarding chorological forms, reference was made to JASPRICA et al. (2017, and references therein). The nomenclature of plant taxa follows the Euro+Med PlantBase (Euro+Med, 2006-2020), except for Campanula austroadriatica D.Lakušić \& Kovačić where the International Plant Names Index was applied (IPNI, 2020). Taxa are associated with vegetation units (classes) using the system of characterizing species reported by Mucina et al. (2016) (i.e., for those plants that are considered 


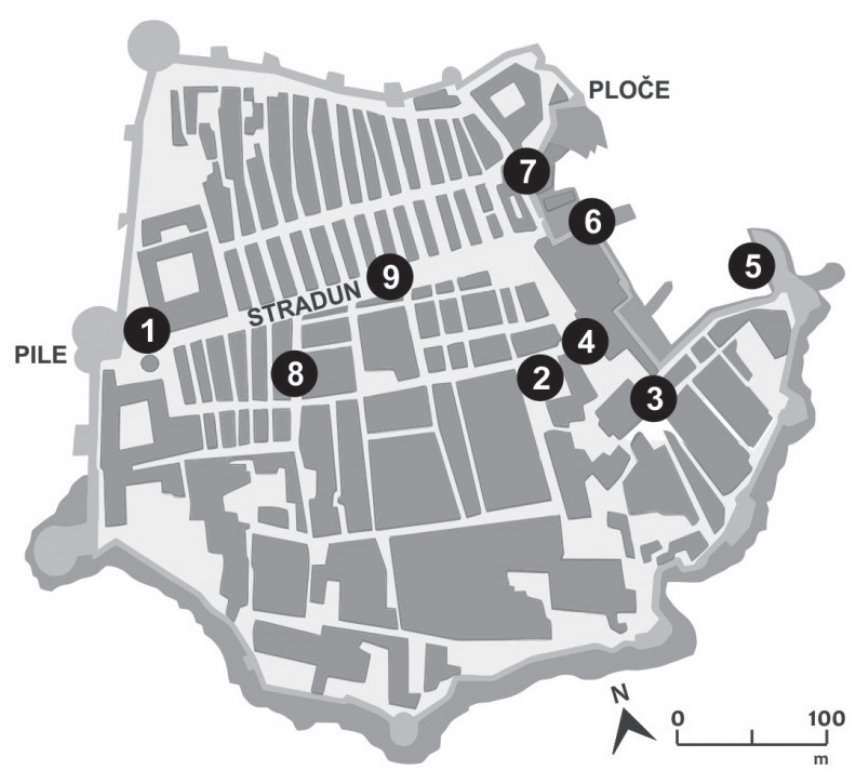

Fig. 1. Position of the study sites on the cobbled streets and pavements within the Old City of Dubrovnik, April 2020: 1 - Large Onofrio Fountain, 2 - Gundulić Square, 3 - Cathedral, 4 - Rector's Palace, 5 - Porporela, St John Fortress, 6 - Old Port area and Luža Square, 7 - Dominican Monastery, 8 - Široka Street, 9 - Stradun (Placa).

'characteristic species' of the classes, see Electronic Appendix S6). The nomenclature of vegetation units also follows Mucina et al. (2016).

The neophytes reported in this study were adjusted according to NiкоLić (2020). To indicate the degree of naturalization (the invasion status) of a taxon, we have used the terms casual, naturalized and invasive, following the definition of RICHARDSON et al. (2000). The assessment of the degree of naturalization was made according to Boršić et al. (2008) refined by Nikolić et al. (2014) and Nikolić (2020).

\section{RESULTS}

In the Old City of Dubrovnik, 60 taxa (57 species and three subspecies) of native and naturalized vascular plants within 25 families and 54 genera were noted (Tab. 1). Families with the highest number of taxa were Compositae (eight taxa, or 13\%), Caryophyllaceae (seven, $12 \%$ ) and Poaceae (five, $8 \%$ ).

The flora is dominated by therophytes (40 taxa, $67 \%$ ) and hemicryptophytes $(11.18 \%)$ followed by geophytes, chamaephytes and phanerophytes (five taxa in each, or 5\%).

The Cosmopolitans (20 taxa, 33\%) followed by a considerable proportion of Mediterranean plants (17.29\%) dominated the flora. Cultivated and adventive plants, South European and Euroasian geographic elements contributed 15\%,13\% and 10\%, respectively.

The most frequent taxa were Parietaria judaica and Erigeron sumatrensis (found at all sites except on Stradun) followed by Polycarpon tetraphyllum (seven sites), and Ochlopoa annua and Cymbalaria muralis (each found at five sites). The number of taxa on the sites 

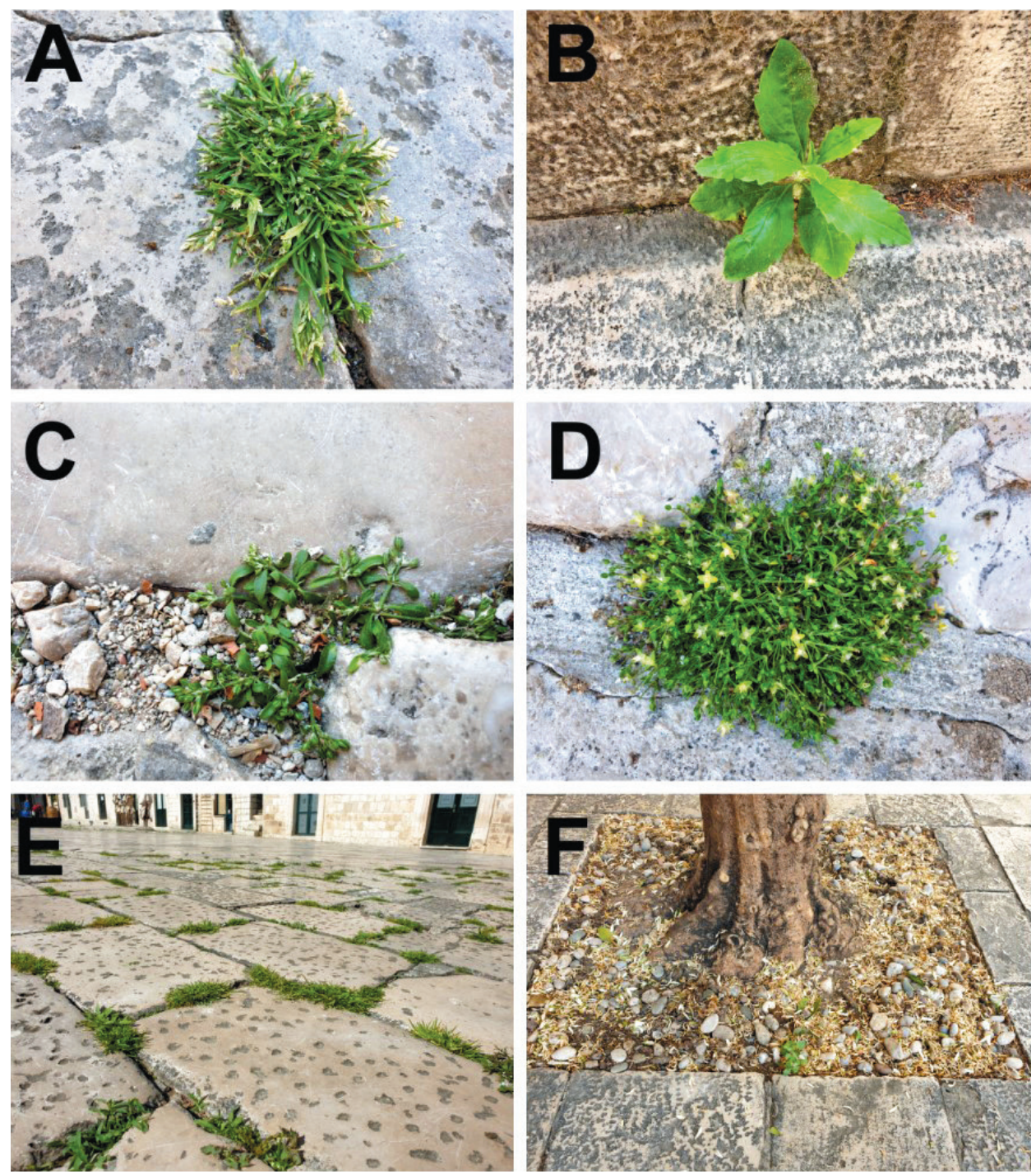

Fig. 2. Some plant species found on the cobbled streets and pavements in the Old City of Dubrovnik in April 2020: A - Ochlopoa annua (L.) H.Scholz, B - Erigeron sumatrensis Retz., C - Polycarpon tetraphyllum (L.) L., D - Sagina maritima Don, E - spontaneous overgrowth of vegetation occurs in the Old City: the Gundulić Square, F - only Parietaria judaica L. and Portulaca oleracea L. were found in a tree circle near the Large Onofrio Fountain, Site 1 (see Šilc et al., 2020) (Photo: N. Jasprica).

was between three and 28, with an average of 14 taxa (SD \pm 7.7$)$; the highest was on Gundulić Square (28) and at the Large Onofrio Fountain (19) and the lowest was in front of the Rector's Palace (3). Along a transect line on Stradun, only five species were noted, exclusively beside manholes or gratings. Only Parietaria judaica and Portulaca oleracea were found in two tree-circles located near the Large Onofrio Fountain, Site 1 (see Šilc et al., 2020, Fig. 2F). 


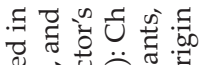

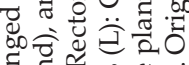
त्ञ $\cong$ जै ฮे 可 สี

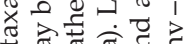
प क 0 ह च च घี

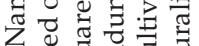

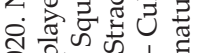
ते. 运它志导志 【ण药

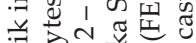

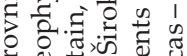

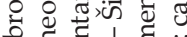

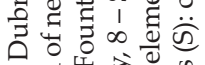

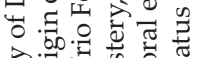

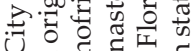

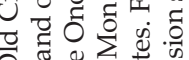
O) . की

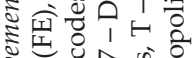
¿

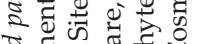

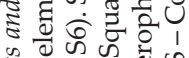

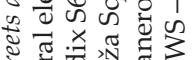
के 문

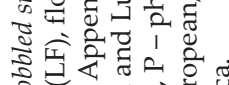
ริำ

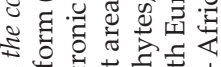

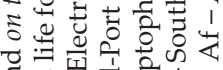

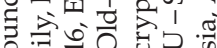
年 20 क्ष

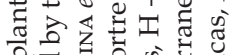

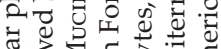

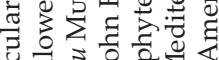

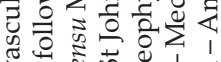

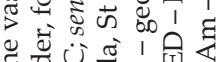

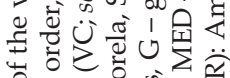

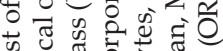

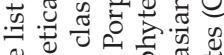

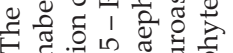

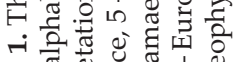

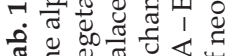

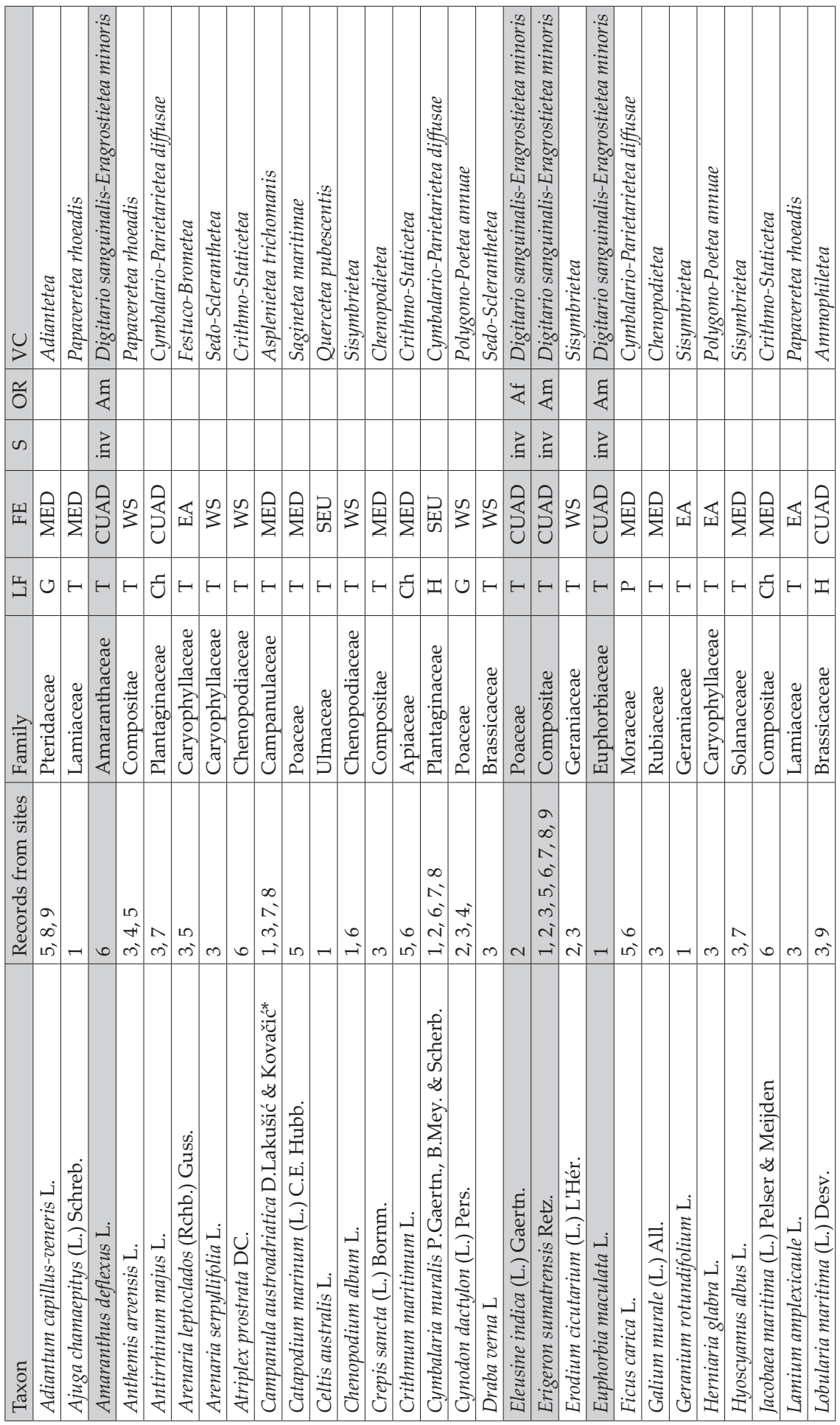




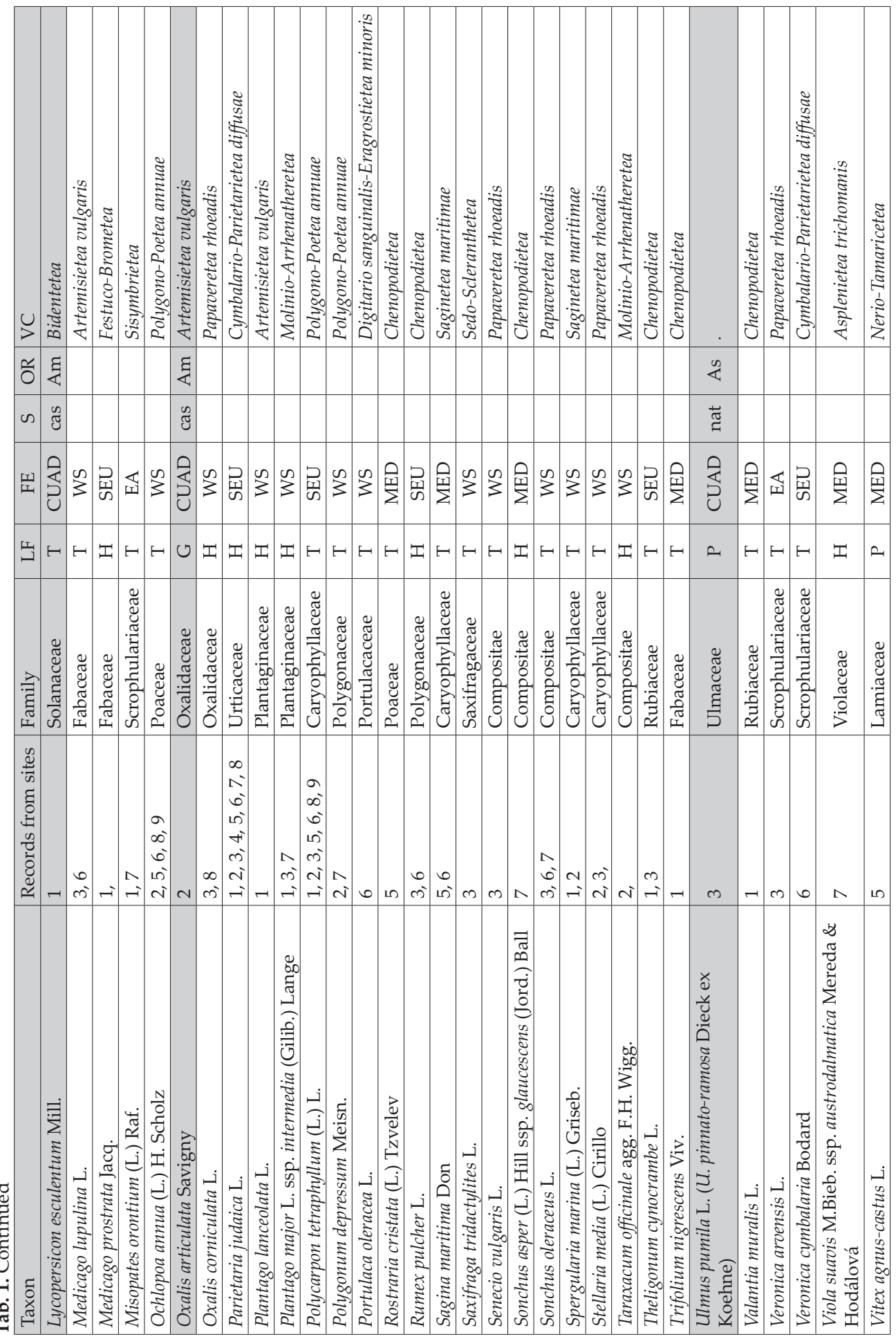


Two taxa (Campanula austroadriatica, Viola suavis ssp. austrodalmatica) are considered to be endemic, belonging to the group of Illyrian-Adriatic endemics (NiкoLić et al., 2015; NiкоLIć, 2020). In addition, two statutorily strictly protected taxa, as statutorily defined in Croatia (Catapodium marinum, Viola suavis ssp. austrodalmatica), are also noted (ANonymous, 2013ab). Additionally, Catapodium marinum is a vulnerable (VU) taxon and listed in the Red Book of Vascular Flora of Croatia (Nikolić \& Topić, 2005; Nikolić, 2020; IUCN, 2020).

Six neophytes were recorded. Among them, the most frequent (present at all sites, except on Stradun) was Erigeron sumatrensis (Tab. 1, Fig. 2B). Up to four taxa found in the Old City are considered to be invasive in Croatian territory.

In the phytosociological spectrum, the largest element was made up of taxa from Papaveretea rhoeadis and Chenopodietea (eight taxa in each, i.e. 13\%), followed by taxa from Digitario sanguinalis-Eragrostietea minoris, Polygono-Poetea annuae, Cymbalario-Parietarietea diffusae and Sisymbrietea (five taxa in each, 10\%).

\section{DISCUSSION}

Although the territory of the city of Dubrovnik includes a wide range of habitats, we have restricted the survey of the area in the Old City to the time in which anthropogenic influences were extremely low. In this study, the location of investigated sites in the Old City of Dubrovnik was mostly in concordance with a heritage crowding map of the sites based on remoteness, area size, area shape, visitor perception and attraction quality (MrĐA \& CARIĆ, 2019: 172). However, we did not estimate the relationship between flora richness and area at particular sites.

In this ecological niche (pavements and squares), the soil is spatially confined and, unlike semi-natural soils, temperatures are always quite high given the close contact with stone materials. These habitats exhibit strong drying conditions and soil compaction due to trampling (LeHMANN, 2006).

Therophytes were dominant in the life-form spectrum, as has been previously reported for the flora of anthropogenic habitats subjected to strong human pressure (see e.g., Salinitro et al., 2018, and references therein). This is not unexpected, as their short generation time and high number of easily dispersed seeds make therophytes very effective colonizers with high tolerance to disturbance. The life-form distribution retains a similarity with the spectrum of the regional pool (e.g., Milović, 2002, etc.). Future studies in the area will show whether the perennials (e.g., Cynodon dactylon) take over the dominant role at these sites later in the year (GRIME, 1979).

The high percentage contribution of Cosmopolitans suggests a high degree of human impact, while co-domination of Mediterranean taxa shows that the Mediterranean climate acts only partially as a strong ecological filter (e.g., DunnetT \& Hitchmough, 2004). Generally, these taxa have a significant influence on the physiognomy of this type of man-made habitat.

Additionally, the phytosociological spectrum, and in particular a considerable participation of taxa from the Papaveretea rhoeadis and Chenopodietea classes, alongside others, indicates that the flora of the studied sites does not retain links with the plant communities of its biogeographic context. Interestingly, the most frequent taxa (e.g., Parietaria judaica, Erigeron sumatrensis and Polycarpon tetraphyllum) are associated with different classes, and they vary considerably according to the type of disturbance, differing at a higher level according to disturbance type. 
The Old City of Dubrovnik hosts some endemics and protected entities. To allow species to thrive in urban areas, management of green spaces and weed control in impermeable areas should take into account the biology and phenology of these species. On the other hand, these plants colonize stone monuments causing conservation problems.

In the present study, neophytes contributed $10 \%$ of identified flora. This is only partly consistent with the proportion of neophytes in urban flora of the main Croatian coastal cities (Jasprica et al., 2010, 2017; Milović \& Mitić, 2012). In general, the pattern of neophytes is most strongly influenced by site conditions (ŠILC et al., 2012). Alongside these, in COVID-19 circumstances, the thousands and thousands of visitors that might have been carrying adventive species on the soles of their shoes were absent.

We are aware that this study covers only a small part of the important aspects of floristic investigations. It contributes to the knowledge of pavement flora during low anthropogenic influence when the spontaneous overgrowth of vegetation also occurred (Fig. 2E). However, data obtained here need to be extended with further investigation later in spring or summer when thermophilic trampled habitats can more usefully be investigated in the Mediterranean macrobioclimate (e.g., ČARnI \& JogAN, 1998). From a purely scientific standpoint, it will be intriguing to define species richness and their phytosociology, present at the same sites in the Old City after the tourist season (i.e., in October 2020), and again next in April 2021, if times get "normal" again. Then, our analysis will contribute to the establishment of a broader understanding of the management and conservation potential of this habitat type. Generally, the flora and vegetation of Dubrovnik city's historical centre have not figured prominently and deserve further investigation.

\section{ACKNOWLEDGEMENTS}

The first author sincerely thanks colleague Dr Mirna Batistić for her support and friendship in early stage of the study. We also thank Steve Latham (UK) for improving the English and the two anonymous reviewers for their helpful comments and the editor for their efforts in improving this report.

Received May 1, 2020

\section{REFERENCES}

Anonymous, 2013a: Zakon o zaštiti prirode. Narodne novine 80/2013.

Anonymous, 2013b: Pravilnik o strogo zaštićenim vrstama. Narodne novine 144/2013.

Boršić, I., Milović, M., Dujmović, I., Bogdanović, S., Cigić, P., ReŠetnik, I., Nikolić, T. \& B. Mitić, 2008 : Preliminarni popis invazivnih stranih biljnih vrsta (IAS) u Hrvatskoj. Natura Croatica 17, 55-71.

CARIĆ, H. \& P. MACKELWORTH, 2014: Cruise tourism environmental impacts - The perspective from the Adriatic Sea. Ocean \& Coastal Management 102A, 350-363.

ČARnI, A., \& N. Jogan, 1998: Vegetation on thermophilic trampled habitats in the Bay of Kvarner. Natura Croatica 7, 45-58.

Dunnett, N. \& J. D. Нiтchmough (eds.), 2004: The Dynamic Landscape: Design Ecology and Management of Naturalistic Urban Planting. London: Spon Press.

Euro+Med, 2006-2020: Euro+Med PlantBase - the information resource for Euro-Mediterranean plant diversity. Published on the Internet htp://ww2.bgbm.org/EuroPlusMed/ [Last access: 24 April 2020].

Grime, J.P., 1979: Plant strategies and vegetation processes. Chichester: John Wiley and Sons.

HARRIs, R., 2006: Povijest Dubrovnika. Zagreb: Golden marketing - Tehnička knjiga. 
Horvat, I., Glavač, V. \& H. Ellenberg, 1974: Vegetation Südosteuropas. Stuttgart: Gustav Fischer Verlag.

IPNI, 2020: International Plant Names Index. Published on the Internet http://www.ipni.org, The Royal Botanic Gardens, Kew, Harvard University Herbaria \& Libraries and Australian National Botanic Gardens. [Last access: 25 April 2020]

IUCN, 2020: Standards and Petitions Committee. 2019. Guidelines for Using the IUCN Red List Categories and Criteria. Version 14 (August 2019). Prepared by the Standards and Petitions Committee. Downloadable from http://www.iucnredlist.org/documents/RedListGuidelines.pdf [Last access: 25 April 2020].

Jasprica, N. \& M. Milović, 2016: The vegetation of the islet of Badija (south Croatia), with some notes on its flora. Natura Croatica 25, 1-24.

Jasprica, N., Milović, M., Dolina, K. \& A. Lasić, 2017: Analyses of flora of railway stations in the Mediterranean and sub-Mediterranean areas of Croatia and Bosnia and Herzegovina. Natura Croatica 26, 271-303.

Jasprica, N., Ruščić, M. \& A. LAsić, 2010: Comparison of urban flora in Split, Dubrovnik and Mostar. Hrvatska misao (Sarajevo) 40, 77-104.

Jasprica, N., Škvorc, Ž., Pandža, M., Milović, M., Purger, D., Krstonošić, D., Kovačić, S., Sandev, D., Lasić, A., Caković, D., AnĐić, B. \& M. Stanišıć-Vujačıć, 2020: Phytogeographic and syntaxonomic diversity of wall vegetation (Cymbalario-Parietarietea diffusae) in southeastern Europe. Plant Biosystems, DOI: 10.1080/11263504.2020.1762794

Köppen, W. \& R. Geiger, 1954: Klima der Erde. Darmstadt: Justus Perthe.

KowARIK, I. \& M. vON DER Lippe, 2018: Plant population success across urban ecosystems: A framework to inform biodiversity conservation in cities. Journal of Applied Ecology 55, 2354-2361.

Lehmann, A., 2006: Technosols and other proposals on urban soils for the WRB (World Reference Base for Soil Resources). International Agrophysics 20, 129-134.

Milović, M., 2002: The flora of Šibenik and its surroundings. Natura Croatica 11, 171-223.

Milović, M. \& B. Mitić, 2012: The urban flora of the city of Zadar (Dalmatia. Croatia). Natura Croatica 21, 65-100.

Milović, M., Kovačić, S., Jasprica, N. \& V. Stamenković, 2016: Contribution to the study of Adriatic island flora: Vascular plant species diversity in the Croatian Island of Olib. Natura Croatica 25, 25-54.

MrĐa, A. \& H. CARić, 2019: Models of heritage tourism sustainable planning. In: Obad Šćitaroci, M., Овар Šćitaroci, B. \& A. Mrøa (eds.). Cultural Urban Heritage, 165-180. The Urban Book Series. Springer Nature Switzerland AG.

Mucina, L., Bültman, H., Dierssen, K., Theurillat, J.-P., Dengler, J., Čarni, A., Šumberová, K., Raus, T., Di Pietro, R., Gavilán Garcia, R., Chytrý, M., Iakushenko, D., Schaminée, J.h.J., Bergmeier, E., Santos Guerra, A., Daniëls, F.J.A., Ermakov, N., Valachovič, M., Pigantti, S., Rodwell, J.s., Pallas, J., Capelo, J., Weber, H.e., Lysenko, T., Solomeshch, A., Dimopoulos, P., Aguiar, C., Freitag, H., Hennekens, S.m. \& L. Tichý, 2016: Vegetation Of Europe: Hierarchical Floristic Classification System Of Plant, Lichen, And Algal Communities. Applied Vegetation Science 19, 3-264.

Nikolić, T. (ed.), 2020: Flora Croatica baza podataka. Available from: http://hirc.botanic.hr/fcd. Botanički zavod, Prirodoslovno-matematički fakultet, Sveučilište u Zagrebu [Last access: 24 April 2020].

Nikolić, T. \& Topić, J. (eds.), 2005: Crvena knjiga vaskularne flore Hrvatske. Zagreb: Ministarstvo kulture Republike Hrvatske, Državni zavod za zaštitu prirode.

Nikolić, T., Mitić, B. \& I. Boršıć, 2014: Flora Hrvatske: Invazivne biljke. Zagreb: Alfa d.d.

Nikolić, T., Milović, M., Bogdanović, S. \& N. JAsprica (eds.), 2015: Endemi u hrvatskoj flori. Zagreb: Alfa d.d.

Pignatti, S., 1982: Flora d'Italia. 1-3. Bologna: Edagricole.

Raunkiaer, C., 1934: The life forms of plants and statistical plant geography. Oxford: Clarendon Press.

Richardson, D. M., Pyšek, P., Rejmánek, M., Barbour, M. G., Panetta, F. D. \& C. J. West, 2000: Naturalization and invasion of alien plants: concepts and definitions. Diversity and Distributions 6, 93-107.

Salinitro, M., Alessandrini, A., Zappi, A., Melucci, D. \& A. Tassoni, 2018; Floristic diversity in different urban ecological niches of a southern European city. Scientific Reports 8, 15110. DOI: https:// doi.org/10.1038/s41598-018-33346-6 
StRÄßER, M., 1998: Klimadiagramme zur Köppenschen Klimaklassifikation. Stuttgart: Klett Verlag. Szlavecz, K., Warren, P. \& S. Pickett, 2011: Biodiversity on the urban landscape. In: R.P. Cincotta \& L.J. Gorenflo (eds.). Human Population: Its Influences on Biological Diversity, Ecological Studies 214, 75-101.

ŠIlc, U., VRbniČAnin, S., BožIĆ, D., ČARni, A. \& Z. Dajić STEvanović, 2012: Alien plant species and factors of invasiveness of anthropogenic vegetation in the Northwestern Balkans - a phytosociological approach. Central European Journal of Biology 7, 720-730.

ŠIlc, U., KüZmič, F., Aćić, S., ĆuŠterevska, R., Jasprica, N., Milanović, D., STeŠEvić, D. \& Ž. ŠKvorc, 2020: Tree-circles spontaneous vegetation over a long climatic gradient. Urban Ecosystems, DOI:10.1007/ s11252-020-00987-3 